\title{
Gun-Sight, Not Shotgun, Nor Gun-Shot
}

\author{
Ziv J. Haskal
}

Received: 8 June 2014/ Accepted: 15 June 2014/Published online: 26 July 2014

(C) Springer Science+Business Media New York and the Cardiovascular and Interventional Radiological Society of Europe (CIRSE) 2014

\section{To the Editor,}

I enjoyed reading the recent article by Fitsiori et al. [1] regarding the use of TIPS in Budd Chiari patients. I am writing to provide one historical clarification for the readers, should they seek the actual description for performing this technique. Within this research, the authors describe treating one patient using the "shotgun" technique, referencing an excellent 2004 report by Bilbao et al. [2]. Within the latter, that technique was described as the "gun-shot" technique. The actual name of this technique is "gun-sight approach," a term that I coined to describe the use of overlapping snares to perform a through-and-through puncture of portal and hepatic veins to create a transcaval portosystemic shunt [3]. That being said, in the majority of cases since that report, I perform a direct transcaval puncture using a coaxial skinny needle through the larger "conventional" Colapinto needle, for these patients.
Conflict of interest Dr. Haskal reports personal fees from Cook Medical, outside the submitted work.

\section{References}

1. Fitsiori K, Tsitskari M, Kelekis A, Filippiadis D, Triantafyllou K, Brountzos E (2014) Transjugular intrahepatic portosystemic shunt for the treatment of Budd-Chiari syndrome patients: results from a single center. Cardiovasc Intervent Radiol 37(3):691-697

2. Bilbao JI, Elorz M, Vivas I, Martínez-Cuesta A, Bastarrika G, Benito A (2004) Transjugular intrahepatic portosystemic shunt (TIPS) in the treatment of venous symptomatic chronic portal thrombosis in non-cirrhotic patients. Cardiovasc Intervent Radiol 27(5):474-480

3. Haskal ZJ, Duszak R Jr, Furth EE (1996) Transjugular intrahepatic transcaval portosystemic shunt: the gun-sight approach. J Vasc Interv Radiol 7(1):139-142

\section{Z. J. Haskal $(\bowtie)$}

Division of Interventional Radiology, University of Virginia School of Medicine, 1215 Lee Street, Charlottesville, VA 22903, USA

e-mail: Ziv2@mac.com 